\title{
DiscoverArchive
}

Retrieved from DiscoverArchive,

Vanderbilt University's Institutional Repository

This work was originally published as Ganesh Sitaraman,

Counterinsurgency and Constitutional Design in 121 Harv. L. Rev.

16222008 .

Please note that the copyright in the Harvard Law Review is held by the President and Fellows of Harvard College, and that the copyright in the article is held by the author. 


\section{COUNTERINSURGENCY AND CONSTITUTIONAL DESIGN}

\section{INTRODUCTION}

Few think of counterinsurgency as linked to constitutional design. ${ }^{1}$ Counterinsurgency is bottom-up; constitutional design is top-down. Counterinsurgency is military; constitutional design is political-legal. Counterinsurgency is temporary, transitional, and tactical, designed to stabilize society; constitutional systems come later and are permanent, constant, and normal. But the conflicts in Iraq and Afghanistan demonstrate the fallacy of these perceptions. Counterinsurgency and constitutional design took place simultaneously, they required high-level political agreement and ground-level acceptance, and they involved politics, law, and security. Iraq and Afghanistan demonstrate that these two enterprises are not different and disconnected, but rather intricately interconnected and complementary.

This Note explores this interconnection, showing how constitutional design and counterinsurgency can influence each other. Part II argues that counterinsurgency is a form of constitutional design. Counterinsurgents have considerable influence over who participates in the constitution-making process. In addition, because counterinsurgency operations can significantly change ground-level power dynamics, and thus the probability of ratification, counterinsurgency may indirectly constrain or expand constitutional design possibilities. Finally, counterinsurgents seek to build a legitimate, stable order within society and to enable public power - elements of what scholars consider the informal constitution of a state. Part III argues that constitutional design can be a form of counterinsurgency. If a constitution is designed with the goals, lessons, and elements of counterinsurgency in mind, the constitution may actually facilitate and accelerate the realization of the counterinsurgent's goals. Part III first provides reasons for including counterinsurgency-inspired design structures in constitutions and then presents examples of such structures. Part IV concludes.

The cases of Iraq and Afghanistan loom large in any contemporary discussion of counterinsurgency or constitution-writing. But even as they enable significant advances in constitutional design, their com-

1 See Rory Stewart, The Prince of the Marshes: And Other OCCupational HAZARDS OF A YEAR IN IRAQ 59 (2007) (stating that the author, who served as deputy governorate coordinator in Maysan province, Iraq, "operated at a level that had nothing to do with new constitutions"). But see David J. Kilcullen, Countering Global Insurgency, 28 J. STRATEGIC STUD. 597, 612 (2005) [hereinafter Kilcullen, Countering Global Insurgency] (explaining that a "constitutional path is needed, but lacking, to counter global jihad"). 
monality may limit the wider applicability of the conclusions drawn here. In both Iraq and Afghanistan, counterinsurgency and constitution-writing occurred simultaneously. Historically, however, insurgency has not overlapped with constitution-writing, and the future may not again provide this dynamic nexus. As importantly, both Afghanistan and Iraq were or became failed states - countries in which the structures of public power were weak, if they even existed. In Afghanistan, the lack of central authority was historically common. In contrast, Saddam Hussein's authoritarian regime had well-functioning structures of public power, but the occupation and the dismantling of the old regime effectively destroyed Iraq's state power. Current counterinsurgency strategy recognizes this phenomenon, in which insurgency often "follows state failure, and is not directed at taking over a functioning body politic, but at dismembering or scavenging its carcass, or contesting an 'ungoverned space.'”2 Finally, in both Iraq and Afghanistan the primary counterinsurgent is the United States, an occupying force. The counterinsurgent may differ in future situations, and the identities and values of future counterinsurgents will have important consequences for the legitimacy of the new order and the degree to which constitutional framing can successfully build on counterinsurgency.

Before exploring the relationship between counterinsurgency and constitutional design, a brief review of the basic elements of insurgency and counterinsurgency is helpful. ${ }^{3}$ Insurgency is the use of military, political, informational, and economic tools to undermine or forestall a legitimate, stable political order. ${ }^{4}$ Success in an insurgency depends on the support, or at least the acquiescence, of the population; 5 to gain support, insurgents may advocate ideologies, ${ }^{6}$ pay locals to conduct insurgency operations, ${ }^{7}$ create disorder, violence, and intimidation, ${ }^{8}$ exploit local grievances and sectarian conflicts, ${ }^{9}$ and in some cases de-

2 David Kilcullen, Counter-Insurgency Redux, SuRvival, Winter 2006-07, at I I I, II 2 [hereinafter Kilcullen, Counter-Insurgency Redux].

3 There are many approaches to counterinsurgency. This Note embraces the approach of recent military scholarship - that of a modern, democratic nation, devoted to human rights and the rule of law. Some prefer a more heavy-handed approach. See, e.g., Edward N. Luttwak, Dead End: Counterinsurgency Warfare as Military Malpractice, HARPER'S MAG., Feb. 2007, at 33.

4 See, e.g., The U.S. Army/Marine Corps Counterinsurgency Field Manual II I-3 (2007) [hereinafter COUNTERINSURGENCy FIELD MANUAL]; Kilcullen, Countering Global Insurgency, supra note I, at 603; Kilcullen, Counter-Insurgency Redux, supra note 2, at I I 2-I4. The literature on contemporary insurgency is dynamic. This Note is limited to the major factors of insurgency relevant to constitutional design in a single state.

5 DAVID GAlula, COUNTER-INSURGENCY WARFARE 7-8 (i g64).

6 Counterinsurgency Field Manual, supra note 4, II I-75.

7 Kilcullen, Counter-Insurgency Redux, supra note 2, at I I 9 .

8 Counterinsurgency Field Manual, supra note 4, If I-28.

9 See Kilcullen, Countering Global Insurgency, supra note I, at 602, 608-09. 
velop a "counterstate" that provides security and essential services. ${ }^{10}$ Counterinsurgency can be defined as the "military, paramilitary, political, economic, psychological, and civic actions taken by a government to defeat insurgency." 11 Success in counterinsurgency operations "depends on the people taking charge of their own affairs and consenting to the government's rule." 12

Three aspects of counterinsurgency are particularly important for constitutional design. First, counterinsurgency proceeds in phases over a long period of time. ${ }^{13}$ For example, in Iraq, a few soldiers developed the "clear-hold-build" framework, which requires counterinsurgents to ensure basic security by clearing the insurgents from an area, and then to hold that area while building up the local institutions of society that enable the indigenous people to hold the area themselves. ${ }^{14}$ The build phase is itself protracted and multi-phased because there is a tradeoff between "speed and national capacity building," 15 such that the host nation "doing something tolerably is normally better than [the counterinsurgent] doing it well." 16

Second, counterinsurgency requires anchoring of strategies and operations to the conditions, culture, and characteristics of the place. Understanding the society and its social structure, culture, language, power, authorities, and interests is essential because those factors influence popular opinion. ${ }^{17}$ Anchoring strategies are essential on the national level and useful, if appropriately tailored, on the subnational level. As the U.S. Army/Marine Corps Counterinsurgency Field Manual notes, "if it works in this province, it might not work in the next." 18

Finally, counterinsurgency operates on multiple tiers - global, national, provincial, and local. At the global level, counterinsurgents

10 Hezbollah is perhaps the best example. See Counterinsurgency Field Manual, supra note 4 , II I-33.

11 Id. II I-2.

12 Id. II I-4. In other words, the population, not the insurgency, is the "center of gravity." David W. Barno, Fighting "The Other War": Counterinsurgency Strategy in Afghanistan, 20032005, MiL. ReV., Sept.-Oct. 2007, at 32, 34.

13 Phases cannot be neatly divided into "crisis" and "development." Military prowess will be necessary during the build phase to maintain security, and the most sustainable security will occur only when the population is involved, which is usually a result of development projects. See Sarah Cliffe, Scott Guggenheim \& Markus Kostner, Community-Driven Reconstruction as an Instrument in War-to-Peace Transitions 4-6 (World Bank Conflict Prevention \& Reconstr. Unit, Paper No. 7, 2003), available at http://info.worldbank.org/etools/docs/library/35 I $22 / \mathrm{WP}_{7}$ final.pdf.

14 See Counterinsurgency Field Manual, supra note 4, II 5-5 I to -80.

15 Klaus Rohland \& Sarah Cliffe, The East Timor Reconstruction Program: Successes, Problems and Tradeoffs I3 (World Bank Conflict Prevention \& Reconstr. Unit, Paper No. 2, 2002), available at http://siteresources.worldbank.org/INTCPR/2 I 4578-I I I I 996036679/20482353/ $\mathrm{WP}_{2}$.pdf.

16 Counterinsurgency Field Manual, supra note 4, II I-I54.

17 Id. II 3-I 9.

18 Id. II I-I55. 
must prevent insurgents from linking to global networks. ${ }^{19}$ Nationally, they must develop coordinated strategies across provinces, consider national politics, and allocate financial and other resources. At the local level, counterinsurgency is mosaic, requiring political, social, cultural, and economic action, in addition to military operations. Counterinsurgents must ensure sewage treatment plants are operating, trash is collected, potable water is available, electrical power is restored, and schools and hospitals are open. ${ }^{20}$ They must "stimulate trade," "rebuild commercial infrastructure," and support economic opportunity, ${ }^{21}$ including "making community improvements" and "forming youth clubs." 22 They must also "develop the initial concept for governance," "identify and recruit local leaders and organizational representatives," "develop local, regional, and national policies and ordinances," and "reestablish [the] justice system." ${ }^{23}$ As General David Petraeus and Lieutenant General James Amos have written, "Soldiers and Marines are expected to be nation builders as well as warriors. They must be prepared to help reestablish institutions and local security forces and assist in rebuilding infrastructure and basic services. They must be able to facilitate establishing local governance and the rule of law." ${ }^{24}$

After writing the Athenian constitution, the lawgiver Solon was asked whether he had devised the best constitution for Athens. He is said to have responded: "The best they could receive." 25 If the challenges of counterinsurgency have any implications for constitutional design, they derive from this lesson. When they occur simultaneously, counterinsurgency and constitutional design are intimately interconnected. To ignore that relationship could result in a constitution that falls far short of the best a people could receive.

19 See Kilcullen, Countering Global Insurgency, supra note I, at 609.

20 Counterinsurgency Field Manual, supra note 4, at I56 fig.5-2. John Nagl describes the role of district officers in I950s Malaya in similar terms: "The district officers' responsibilities extended ... to 'the inauguration and guid[a]nce of elected local councils'; 'the fostering of Civics Courses'; 'improvements to... water supplies, bridle paths, the provision of electric lights'; and 'land administration generally." JOHN A. NAGL, LEARNING TO EAT SOUP WITH A KNIFE: COUNTERINSURGENCY LESSONS FROM MALAYA AND VIETNAM IOO-OI (Univ. of Chi. Press 2005) (2002).

21 Counterinsurgency Field MANUAL, supra note 4, at I56 fig.5-2.

22 Id. II 5-75.

23 Id. at 156 fig. $5-2$.

24 David H. Petraeus \& James F. Amos, Foreword to Counterinsurgency Field MANUAL, supra note 4, at xlv, xlvi; see also COUNTERINSURGENCY FIELD MANUAL, supra note 4, at 156 fig.5-2; id. II 5-75; NAGL, supra note 20, at Io0-0I; David Kilcullen, "Twenty-Eight Articles": Fundamentals of Company-Level Counterinsurgency, MIL. REv., May-June 2006, at I03, IO7 [hereinafter Kilcullen, Twenty-Eight Articles]; Sarah Sewall, Introduction to the University of Chicago Press Edition of COUNTERINSURGenCy Field MANUAL, supra note 4, at xxi, xxxii.

25 i Plutarch, Plutarch's Lives i30 (Dryden ed. rev., J.M. Dent \& Sons i970). 


\section{Counterinsurgency as Constitutional Design}

Most military personnel probably do not think of themselves as participating in the process of constitutional design, but counterinsurgency can actually be a form of constitutional design. First, constitutions are created through a process of bargaining by competing groups within society. As a powerful force within society, the counterinsurgent has influence over which groups participate in the constitutionmaking process, and therefore over the ultimate constitutional bargain they strike. Second, counterinsurgency operations can reshape power dynamics and preferences within society. Constitution drafters may have to reconsider constitutional provisions because the ratifiers' preferences have changed. Finally, because counterinsurgents seek to develop a stable, legitimate political and social order at the ground level, they shape the habits, processes, and institutions that enable the use of public power. Scholars consider these features the "informal constitution" of a country; counterinsurgents are thus unwitting constitutional designers. This Part considers in turn these three ways in which counterinsurgency is a form of constitutional design.

\section{A. Choosing Constitutional Designers}

A leading theory conceives of constitutions as bargains among competing groups. ${ }^{26}$ Constitutions should not be understood as contracts, which imply mutual exchange between parties, normative agreement and obligation, and enforcement through external sanctions - features often missing from constitutions. ${ }^{27}$ Rather, constitutions arise out of a "coordination dilemma," the fact that society needs a set of institutional structures in order to coordinate basic functions, achieve stability, and unify civic culture. ${ }^{28}$ Under a coordination theory, elite groups compete, compromise, and eventually develop a "focal equilibrium," a set of functional governance structures to which all groups will acquiesce. ${ }^{29}$ To be sure, popular opinions influence elite behavior, but elites, not the masses, determine the particular provisions chosen $^{30}$ and are thus the central actors in the constitution-making process. Coordination theory presupposes the elite parties who par-

\footnotetext{
26 See, e.g., Russell Hardin, Liberalism, Constitutionalism, And Democracy I2-I8, 82-I33 (I999); Adam Przeworski, Democracy as a Contingent Outcome of Conflicts, in Constitutionalism AND Democracy 59, 63-64 (Jon Elster \& Rune Slagstad eds., I993); Barry R. Weingast, The Political Foundations of Democracy and the Rule of Law, 9I AM. POL. SCI. REV. 245, 257-58, 26I (I997).

27 See HARDIN, supra note 26 , at 88-89.

28 Id. at 87-88; $c f$. Weingast, supra note 26, at 253 (arguing that resolution of "coordination dilemmas" leads to stable democracy and shared citizen values).

29 Weingast, supra note 26 , at 258.

30 See id. at 246 .
} 
ticipate in the constitution-making process; it does not explain how they come to participate.

When counterinsurgency and constitution-making occur simultaneously, the counterinsurgent will have considerable influence, although not complete power, over who participates in the constitution-making process. If a foreign counterinsurgent is initiating the constitutionmaking process, it may think of itself as above the competition between groups jockeying for influence in the drafting process. The counterinsurgent could hand pick the participating groups and thus have considerable power over the final constitutional structure. But more often than not, a foreign counterinsurgent will not be completely above the competition. Rather, the counterinsurgent will be one actor among many, and it will have to work with other power holders to determine who will participate in the drafting.

Iraq's constitution-making process is an exemplary case: the Coalition Provisional Authority (CPA), although initially reluctant, eventually acquiesced to negotiations with the other groups in society to determine who would be included in the drafting process. At first, the CPA wanted a new Iraqi constitution to "be drawn up by expert Iraqis, and then presented to the public and endorsed by a referendum."31 Ayatollah Ali Sistani, a powerful Shia cleric, found the plan unacceptable, and announced that the only legitimate approach would involve elections to a constitutional assembly, followed by popular ratification. ${ }^{32}$ The CPA thus found itself in a difficult position: "Either it accepted an elected body that might not prove amenable to its pressures, or it had to face the possibility of rejection of the constitution if it were produced by an appointed group, no matter how 'representative' they appeared to be." 33 In order to mollify Sistani, the CPA pronounced the November I5 agreement, which provided for direct election to the constitutional convention. ${ }^{34}$ The November I5 agreement demonstrates that the CPA had a central role in determining the procedures for participation in the constitution-making process, but still had to work with other powerful groups in society to negotiate an acceptable structure for that process. Which groups participated was neither predetermined nor dictated by the counterinsurgent. But in exerting influence over the process of who was included, the counterinsurgent had considerable power to shape the ultimate outcome of the constitution.

\footnotetext{
31 Ali A. Allawi, The Occupation Of IRAQ i69 (2007).

32 Noah Feldman, The Democratic Fatwa: Islam and Democracy in the Realm of Constitutional Politics, 58 OKLA. L. REV. I, 6 (2005).

33 ALLAWI, supra note 3I, at 2 I I.

34 See LARry Diamond, Squandered Victory: The American OcCupation and THE Bungled EFForT TO BRING DEMOCRACY TO IRAQ 5 I-52 (2005).
} 


\section{B. A Dynamic Theory of Upstream and Downstream Constraints}

After the drafters of the constitution are chosen, counterinsurgents can still have a significant influence on the drafting of the constitution due to the constraints facing the drafters. Professor Jon Elster famously distinguished between two types of constraints endemic to the constitution-writing process: "Upstream constraints are imposed on the assembly before it starts to deliberate. Downstream constraints are created by the need for ratification of the document the assembly produces." 35 Because constitutional conventions are usually established by an initiator, such as a legislature, executive, or occupying power, the initiating authority can place "upstream" constraints on the constitution writers regarding matters of procedure or substance. ${ }^{36}$ In the United States, for example, the Continental Congress mandated that the Philadelphia Convention revise the Articles of Confederation, not create a new constitution. ${ }^{37}$ Although the drafters may seek to exceed such constraints, as the American founders did, the cost of doing so is at least a strong disincentive and may even be prohibitive. At the same time, downstream constraints exist in the drafters' knowledge of the ultimate need for ratification. Drafters must consider the preferences of the ratifying body, whether it be a legislature, the executive, or the public via referendum. ${ }^{38}$ For example, during the Philadelphia Convention, the drafters were constrained by the divisions between the small and large states and the northern and southern states.

This static model of upstream constraints and downstream ratification preferences does not tell the whole story. The initial upstream and downstream constraints may change dramatically if some intervening event modifies the ratifiers' preferences. ${ }^{39}$ Consider the following scenario: During constitutional deliberations, an intervening event substantially changes the ratifiers' preferences. Concerned by these new preferences, the initiator may change the rules of the game, announcing new upstream constraints that the drafters must consider. Even if the initiator does not react, the drafters still face new downstream constraints based on the change in the ratifiers' preferences.

35 Jon Elster, Essay, Forces and Mechanisms in the Constitution-Making Process, 45 DukE L.J. 364, 373 (1995). The distinction, he notes, is not perfect because one upstream constraint may be who constitutes the ratifiers, that is, who will become the downstream constraint. Id. at 37475 .

36 Id. at $373-74$.

37 Id. at 374 .

$38 I d$.

39 Professor Elster notes that discussion and argument may change preferences and that extrapolitical forces - the threat of "the troops and the crowds," id. at 393 - can suspend constitution-making processes, but he does not explore how they influence substantive deliberations. See $i d$. at $390-93$. 
As constraints shift, so will the constitutional provisions that the drafters can choose to include or exclude.

Under this dynamic model, three factors are important for determining the potential for changes in the drafting-room: the power of the initiator, the type of ratifying body, and the character of the intervening event. Depending on the initiator's power over the constitutional assembly and within the society, the initiator's changing of the upstream constraints may have more or less influence over the drafters. Occupiers and waning regimes, for example, will have varying degrees of authority. The type of ratifying body will also influence the extent of change in ratifiers' preferences. If the body is an assembly with relatively long terms of office, for example, it may be insulated from changes in popular preferences. If the ratifying body is the populace, then popular preferences are themselves the constraints facing drafters, so changes in the public's view will have direct and immediate impact. Finally, the character of the intervening condition is significant. Power dynamics in society may change due to foreign interventions or wars, insurgencies, economic troubles, natural disasters, famines, or even the simple evolution of preferences over time. Each type of intervening condition will impact power dynamics in different ways.

Counterinsurgency provides a clear illustration of the dynamic nature of upstream and downstream constraints. Counterinsurgency reshapes ground-level power dynamics and influences popular preferences. Because the constitutional drafting process occurs simultaneously, successful or failed counterinsurgency operations will undoubtedly change the population's preferences, thereby implicating the constitution. First, the counterinsurgent's decisions to ally with or empower certain groups may have an effect on the status of those groups within society. Groups may be stigmatized by their affiliation, empowered through cooperation, or even exalted because excluded. Second, security operations can influence ground-level power dynamics. Excessive shows of force or brutal tactics such as torture may delegitimize the counterinsurgent and create a backlash within society that results in greater support for particular factions. Third, backlash against the counterinsurgent may undermine the counterinsurgency's approach to political institutions more generally: a loss of legitimacy for the occupier may lead to a loss of legitimacy for the occupier's values. Finally, and not to be excluded, the insurgents' tactics may also affect ground-level dynamics. Insurgents may attack particular factions or assassinate leaders, diminishing or increasing sympathy for those factions. Any of these factors can reshape power dynamics in society, and if the power shifts are substantial enough, they will be felt in the drafting room. 


\section{Unwitting Constitutional Designers}

In addition to influencing the parties who write the constitution and the constraints faced by drafters, counterinsurgents can actually act as constitutional designers themselves. To understand how counterinsurgency is a form of constitutional design, it is necessary to distinguish a country's formal and informal constitutions. ${ }^{40}$ The former is the written constitution, which lays out the legal institutions that frame society. The latter is more difficult to define, but it includes the foundations for power and public order. ${ }^{41}$ It consists of the "assemblage of laws, institutions and customs ... that compose the general system." 42 These elements are what make formal constitutionalism and stability and order more generally — possible.

Counterinsurgents are constitutional designers because one of their tasks is to build these shared, accepted norms and practices, which enable and empower government. ${ }^{43}$ Because the existence of an insurgency means that authority and power within society are fiercely contested, there is no commonly accepted set of norms, customs, and power structures that can be said to comprise the informal constitution. The counterinsurgent must enable the exercise of public power in society through its operations, in the process establishing shared norms, customs, and practices for how power will be exercised. Thus, the decisions counterinsurgents make on seemingly narrow, local concerns may have consequences of a constitutional magnitude. In making choices about which structures to establish, which local groups to include, or even which approaches to use when ensuring security and providing social goods, counterinsurgents are in effect designing the "constitution" in its most basic, primordial manifestation: they are creating and fortifying the informal constitution.

\section{Constitutional Design AS COUNTERINSURGENCY}

If counterinsurgency can be a form of constitutional design, then perhaps the reverse is equally true - constitutional design can be a

40 This Note uses "constitution" to refer to the written constitution, specifying "informal" when the informal constitution is intended.

41 Cf. Frank I. Michelman, Constitutional Authorship, in Constitutionalism 64, 70 (Larry Alexander ed., I998) (describing the small- $c$ constitution and the big- $C$ Constitution); Michael J. Perry, What Is "the Constitution"? (and Other Fundamental Questions), in ConstiTUTIONALISM, supra, at 99, 99 (distinguishing between Constitution ${ }_{1}$, the text, and Constitution ${ }_{2}$, norms that constitute the supreme law of the land); Ernest A. Young, The Constitution Outside the Constitution, II7 YALE L.J. 408, 4I5 (2007) (identifying the canonical and extracanonical Constitution).

42 Henry St John Bolingbroke, A Dissertation upon Parties, in Political WritINGS I, 88 (David Armitage ed., I 997) (I 733-34) (emphasis added).

43 See supra pp. 1624-25. 
form of counterinsurgency. Counterinsurgency seeks to build a legitimate, stable set of political structures that channel power within a society; constitutions provide particular canals through which public power is legitimately channeled. It may be possible, then, to use the constitution as a tool to assist the counterinsurgent in building these political structures and channeling power within society. Section A argues that counterinsurgency-inspired provisions should be included in constitutions,$^{44}$ focusing on the ability of constitutions to accelerate the creation of legitimate self-government. Sections B through D present design structures inspired by the lessons of counterinsurgency strategy - namely, that counterinsurgency proceeds in phases over time, must be anchored to local conditions, and should be tiered and mosaic. ${ }^{45}$ Constitutional designers and counterinsurgents alike should consider using these strategies.

\section{A. Why Constitutionalize Counterinsurgency}

I. The Constitution as a Tool for Counterinsurgency. - In cases of counterinsurgency, the state is not a consolidated democracy - "a political regime in which democracy as a complex system of institutions, rules, and patterned incentives and disincentives has become, in a phrase, 'the only game in town.'" 46 Indeed, modern insurgency usually takes place in failed states. The optimal solution would be to defeat the insurgency and establish security prior to seeking constitutional government or democratic processes. But this desired sequence may not always be possible - due either to the rushed policies of the counterinsurgent or to international or domestic pressure for selfgovernment. Perhaps more importantly, counterinsurgency strategy itself is not purely military; it involves political, economic, and social tactics as well. Because the counterinsurgent's project is intertwined with the creation of consolidated democracy through nation building, ${ }^{47}$ it may, as a result, be impossible to sequence counterinsurgency prior to a democratic constitution. ${ }^{48}$

\footnotetext{
44 A brief caveat: The strategies presented here are derived from counterinsurgency theory. Particular counterinsurgents or constitutional designers will have political and strategic goals based on their self-interest, ideology, experience, or other factors. This Note ignores these contextdependent goals, not because they are unimportant, but in the hope of highlighting mechanisms that apply across contexts.

45 See supra pp. I624-25.

46 Juan J. Linz \& Alfred Stepan, Toward Consolidated Democracies, J. DemocraCy, Apr. I996, at I4, I5.

47 See Counterinsurgency Field Manual, supra note 4, II D-38 ("Establishing the rule of law is a key goal and end state in [counterinsurgency].").

$48 \mathrm{Cf}$. Kilcullen, Twenty-Eight Articles, supra note 24, at I07 ("Counterinsurgency is . . an attempt to redress basic social and political problems while being shot at.").
} 
Constitutions, in contrast, are premised on the acceptance of state power as legitimate. If significant strife exists on the ground or the government is not accepted by the people, then the constitution may become a "façade constitution." 49 A façade constitution can declare aspirational principles and adopt power structures for government, but such provisions and principles are ineffective and potentially delegitimized because they are not followed in practice. ${ }^{50}$ Many African constitutions, for example, were not tailored to their social context and were either ignored or manipulated, thereby undermining constitutionalism and the rule of law. ${ }^{51}$ Insurgency, by definition, undermines a shared constitutionalism. Rory Stewart perhaps puts it best: "It did not matter what human rights were enshrined in documents if your local sheikh, party leader, or policeman could still beat you up on the street corner." ${ }^{2}$

Counterinsurgency-inspired constitutional provisions have the potential to narrow the gap between the uncertainty on the ground and the stability constitutions require. Instead of seeing the constitution as presupposing a degree of legitimacy and public power, constitutional designers should see the constitution as a tool to help build legitimacy and public power. Indeed, constitutions have often been understood as empowering and enabling self-government, rather than just restraining government power. ${ }^{53}$ Professor Edward Corwin characterizes this idea as the "constitution as instrument," and argues that constitutions need to empower the government to address "things needing to be done in the future." W4 When a government is not empowered to act, it cannot ensure "peace or stability for [its] populations or control [its] territories" or provide "any reasonable distribution of social goods." 55 The idea of "constitution as instrument" can be adapted to assist counterinsurgents, who need to build state power and self-government in order to win over the population and end the insurgency. To be sure, constitu-

49 Giovanni Sartori, Constitutionalism: A Preliminary Discussion, 56 Am. POL. SCI. REV. 853 , 86 I (1962).

50 See Noah Feldman, Imposed Constitutionalism, 37 CoNN. L. REv. 857, 872 (2005). This is consistent with the idea that a constitutional "rule of recognition is a social fact." Young, supra note 4I, at $42 \mathrm{I}$; see also Michelman, supra note $4 \mathrm{I}$, at $7 \mathrm{I}$.

51 See generally H.W.O. Okoth-Ogendo, Constitutions Without Constitutionalism: Reflections on an African Political Paradox, in Constitutionalism AND Democracy 65 (Douglas Greenberg et al. eds., I993).

52 STEWART, supra note I, at 339.

53 See Michael W. McConnell, Textualism and the Dead Hand of the Past, 66 Geo. Wash. L. REV. I I27, II30 (I998) (arguing that constitutional rules might enable, rather than constrain, selfgovernment).

54 Edward S. Corwin, The Constitution as Instrument and as Symbol, 30 AM. POL. SCI. Rev. I071, I072 (I936).

55 Rosa Ehrenreich Brooks, Failed States, or the State as Failure?, 72 U. CHI. L. REV. I 59 , I I60 (2005). 
tions with or without counterinsurgency-inspired provisions will help empower government to some degree. But constitutions inspired by counterinsurgency may accelerate the development of effective selfgovernance.

First, counterinsurgency-inspired constitutions can act as a more effective focal point for action. ${ }^{56}$ The specific provisions in the constitution's text will provide guidance to local leaders and counterinsurgents on setting up governance structures, facilitating development, and empowering leaders. In failed states, and particularly in failed states without a tradition of democracy or self-government, even the basic tasks of setting up civil society organizations, creating local governments, or conducting elections can be incredibly difficult. ${ }^{57}$ Constitutionalizing those basic structural components will both enable local populations to create and participate in these structures, and reduce debate and conflict over how to establish those structures by a substantial amount. In other words, constitutionalizing these structures lowers the initial cost of creation and thereby accelerates their establishment through ease of coordination. ${ }^{58}$ Statutes could also establish these structures, but in failed and failing states, a constitution may be preferable not only because it might be promulgated with greater fanfare and distributed more widely across the country, but also because it would likely be read aloud and discussed at local gatherings, which would be particularly important in areas of lower literacy. Constitutionalizing these provisions thus announces loudly and clearly what powers the people have to govern themselves. Statutes are meek in comparison.

Additionally, the constitution provides a clear signal that empowers - and thereby legitimizes - local leadership and holds them accountable. Constitutionalizing these structures signals, both to the domestic population and to international aid organizations, the identity of the political officials responsible for establishing and delivering basic social services. The signaling effect also applies to the leaders themselves, who will self-identify as serving in constitutionally created posts. They will likely feel a greater sense of responsibility and will certainly feel a greater sense of authority, both of which should strengthen the legitimacy of their positions. Crucially, with empowerment comes accountability. Constitutionalizing the lessons of counter-

\footnotetext{
56 Cf. David A. Strauss, Common Law Constitutional Interpretation, 63 U. CHI. L. REv. 877 , 910-I I (1996) (analogizing the conventionalist justification for adherence to the Constitution to focal points in game theory).

57 See Stephen D. Krasner \& Carlos Pascual, Addressing State Failure, Foreign AfF., JulyAug. 2005, at I53, I59-60.

58 For a helpful discussion of constitutions as coordination-oriented documents, see HARDIN, supra note 26 , at $85-90$.
} 
insurgency informs domestic and international communities of who is accountable for progress. Accountability will prevent local leaders from passing the blame either upward to the central government or across to the counterinsurgent.

2. Challenges to Counterinsurgency-Inspired Constitutional Design. - Despite these benefits, constitutional theory suggests three counterarguments to constitutionalizing the lessons of counterinsurgency: endurance, flexibility, and moral rights. The endurance counterargument claims that because constitutions are meant to be lasting documents, ${ }^{59}$ presentist concerns are inappropriate. However, constitutions may not be long-term documents, but rather structures to achieve immediate governance goals. Despite the near-worshipful reverence for the public spirit of the American founders, constitutions are not born from enlightened processes but from messy compromises and short-sighted interests. ${ }^{60}$ The U.S. Constitution, for example, dodged one of the most pressing long-term issues for the nation - slavery by compromising on the Three-Fifths Clause $^{61}$ and by promising no interference with the slave trade for twenty years. ${ }^{62}$ These short-term fixes enabled the Constitution to come into being; they were not designed for all time. The endurance counterargument also assumes a preconstitutional stability that is absent in insurgencies. If the shared norms and practices of society are undecided, establishing a constitution for all time necessarily places that constitution on shaky ground.

The flexibility argument claims that entrenching provisions designed for short-term projects undermines future generations' ability to adapt to changed conditions. In an insurgency, focusing on future flexibility seems unwise; if a functioning state does not arise, future generations will have no need for flexibility. Alternatives exist that can ensure flexibility in the future: the constitution could include timelimited provisions, renewable provisions, provisions that give locales a choice of pathways to follow, and diverse amendment procedures that entrench different provisions to different degrees. Additionally, interim constitutions may be an effective way to incorporate counterinsurgency-inspired provisions while not entrenching them. A more significant critique is that counterinsurgents need flexibility and that entrenching structures into the constitution, although it builds legitimacy and encourages participation, will limit their choices. This challenge highlights a fundamental tension between a counterinsurgent's

\footnotetext{
59 See, e.g., McCulloch v. Maryland, I7 U.S. (4 Wheat.) 316, 4I5 (I8I9) (noting that the U.S. Constitution was intended "to endure for ages to come, and, consequently, to be adapted to the various crises of human affairs").

60 See supra p. I626.

61 U.S. ConsT. art. I, $\S 2$, cl. 3 , amended by U.S. ConST. amend. XIV, § 2.

$62 I d$. art. I, $\S 9$, cl. I.
} 
tactical need for flexibility and its strategic need for legitimacy and capacity building. It should perhaps be added to the Counterinsurgency Field Manual's paradoxes of counterinsurgency ${ }^{63}$ : sometimes, the more flexibility you have, the less effective you will be.

Finally, the moral rights argument claims that accommodating the present situation, even partially, may condone unacceptable or immoral practices, thus contravening human rights; conversely, specifying rights that are presently unattainable may help bring those rights into effect. ${ }^{64}$ Extreme divergences between human rights and local practices must be guarded against, but some compromise between local culture and Western values will be necessary to ensure the success of the constitutional project. In Iraq, for example, advocating for the strict separation of church and state would have been counterproductive, as the decision to make Islam the state religion was "entirely uncontroversial." 65 If the counterinsurgent forces upon a new nation an idealistic constitution that runs counter to the nation's traditions and culture, the constitution may be ignored, jettisoned, or used as a mere political tool. In failed states, the success of some kind of constitutionalism may be preferable to the failure of any kind of order. ${ }^{66}$

\section{B. Phased-In Constitutionalism}

The first important lesson of counterinsurgency is that it proceeds in phases over a long period of time - from creating security to building sustainable social, political, and economic institutions. ${ }^{67}$ This lesson suggests two design strategies. First, time-limited or renewable constitutional provisions may be helpful, particularly for ensuring security. Provisions that grant the police or occupying security forces greater powers for a short period of time may be helpful for ensuring that the "clear" phase of clear-hold-build is effective and legitimate. Second, establishing an interim constitution that exists for a relatively long period of time, until stability can be confidently predicted, may be effective. The field of interim constitutional design and politics is too complex for a sufficient treatment in this Note, but there may be many helpful design strategies that would be problematic to entrench into permanent constitutions. An interim constitution could delineate the scope of an occupying force's mission and operations. It could assist the counterinsurgent's initial offensive operations by identifying certain groups, practices, or actions as unconstitutional. Professor

\footnotetext{
63 Counterinsurgency Field Manual, supra note 4, III I-I 48 to -I 57.

64 See Feldman, supra note 50, at 873.

65 Noah Feldman \& Roman Martinez, Constitutional Politics and Text in the New Iraq: An Experiment in Islamic Democracy, 75 FORDHAM L. REV. 883, 903 (2006).

66 Cf. Feldman, supra note 50, at 872-74.

67 See supra p. I624.
} 
Stephen Krasner has suggested a policy of shared sovereignty over certain sectors, ${ }^{68}$ an idea that could be incorporated into an interim constitution. Finally, an interim constitution could outline a clear path to sovereignty, one that passes authority from the counterinsurgent to the domestic population as certain goals are met.

\section{Constitutional Anchoring}

Effective counterinsurgency requires understanding and adapting to the particular conditions, cultures, and characteristics of a place. ${ }^{69}$ As the Counterinsurgency Field Manual notes, "if it works in this province, it might not work in the next." 70 None of the design structures presented here, therefore, should be universally applied - context matters. Focusing on the uniqueness of the place provides four methods for how constitutional designers can anchor the constitution to the place: address local grievances, incorporate cultural norms, include neotraditional governance structures, and know the population.

I. Address Local Grievances. - Constitutional designers should attempt to address and neutralize local grievances, thereby depriving global insurgency networks of discontented potential recruits. ${ }^{71}$ The most evident forms of local grievance relate to human rights and to divided societies. During the I950s, for example, Sir Gerald Templer took measures toward social and political equality for all groups in Malaya. $^{72}$ Addressing the grievance - a history of certain groups not having political and social rights - reduced the number of disaffected persons and the number of possible recruits to the insurgency. The problem of divided societies is evident in Iraq. The Shia, Sunni, and Kurds all had local grievances. The Shia had experienced a history of repression and lack of political control despite being a majority of the population. ${ }^{73}$ The Sunni, having held power for so long, were now anxious about the future. ${ }^{74}$ And the Kurds, who had experienced persecution, were unwilling to cede relative autonomy to a majoritarian Arab state. ${ }^{75}$ Neutralizing these grievances by finding a way for the three groups to coexist was, and remains, a central challenge. Much has been said about how to mitigate conflict in divided societies; ${ }^{76}$ con-

\footnotetext{
68 Stephen D. Krasner, The Case for Shared Sovereignty, J. DEMOCRACY, Jan. 2005, at 69.

69 See supra p. I624.

70 Counterinsurgency Field MANUAL, supra note 4, II I-I55.

71 See Kilcullen, Countering Global Insurgency, supra note I, at 608-09.

72 See Kalev I. Sepp, Best Practices in Counterinsurgency, MIL. ReV., May-June 2005, at 8, 9.

73 See Allawi, supra note 3I, at I37.

74 See id. at $240-4 \mathrm{I}$.

75 See id. at $73,22 \mathrm{I}-23$.

76 See, e.g., Arend Lijphart, Democracy in Plural Societies (i977); Edward Schneier, Crafting Constitutional Democracies (2006); Arend Lijphart, Constitutional Design for Divided Societies, J. DemocraCy, Apr. 2004, at 96.7
} 
stitutional mechanisms such as federalism, ${ }^{77}$ concurrent majorities, ${ }^{78}$ minority vetoes, and partition are but a few of the possible solutions.

In addition to these national-level grievances, there may be community-level grievances. Particular tribal, minority, cultural, or linguistic groups may have concerns that, if addressed, would increase their likelihood of supporting the counterinsurgent's government-increation. Designing structures to address these grievances will obviously depend on the particular grievance and situation. The important lesson is that addressing national and community grievances will assist in counterinsurgency because it will eliminate the fuel for disaffection and insurgency.

2. Incorporate Cultural Norms. - Keeping a constitution relevant and winning the support of the population require drafting a constitution that fits within the basic preconstitutional values and philosophy of the population - even when these cultural norms contravene the beliefs or preferences of the counterinsurgent or constitution drafters. Iraq and Afghanistan are both Islamic states; Iraq's constitution allows Islam to be "a source" of law, ${ }^{79}$ and Afghanistan's constitution provides that no law can be contrary to Islam. ${ }^{80}$ A pure separation of Islam and the state was never even considered. ${ }^{81}$ Even the Japanese constitution, imposed from outside by General MacArthur after World War II, retained the emperor in a titular position, despite the obvious incongruence with American ideas of democracy, because eliminating the emperor from the political system would have caused considerable upheaval within Japan. ${ }^{82}$

3. Include Neotraditional Governance Structures. - Local areas have unique cultural traditions and thus may have traditional governance structures that can be incorporated into the constitution. ${ }^{83} \mathrm{Be}-$ cause local populations will be familiar with the structure and functions of traditional governance, they may be more inclined to accept and embrace them compared to externally devised and culturally un-

77 See, e.g., Nancy Bermeo, The Import of Institutions, J. DEMOCRACY, Apr. 2002, at 96; Lijphart, supra note 76 , at 104-05.

78 See generally John C. CALhoun, A Disquisition on Government, in UNION AND LIBerty: The Political Philosophy of John C. Calhoun 3 (Ross M. Lence ed., i992) (I85I).

79 IRAQ CONST. art. 2

80 AFG. CONST. ch. I, art. 3.

81 See Feldman \& Martinez, supra note 65 , at 903 \& n.80.

82 Ray A. Moore \& Donald L. Robinson, Partners For Democracy: Crafting THE NEW JAPANESE STATE UNDER MACARTHUR 49 (2002).

83 There is a tension between the idea that counterinsurgency can create and change dynamics on the ground, see supra p. 1629, and the suggestion that drafters incorporate existing governance structures. Context will determine which approach dominates, but even if ground-level dynamics are in flux, traditional structures may be within the historical and cultural memory of the population and thus usable as anchoring structures for governance. 
familiar structures. Additionally, incorporating traditional governance structures will help keep the constitution socially relevant and linked to power realities on the ground. Of course, traditional institutions will likely need to be updated and reformed in order to comport with modern ideas of human rights and democracy. Hence, the governance structures should be "neotraditional" - including the core of the traditional institutions, but revising practices of composition and eligibility to meet international norms.

Constitutional drafters could potentially follow two approaches to incorporating traditional governance structures. First, they could incorporate any and all forms of traditional authority with their own customary laws, subject to legislation. The South African Constitution follows this approach, recognizing traditional leadership and providing for its role in local affairs. ${ }^{84}$ Second, constitutional designers could incorporate specific traditional governance structures into the constitution. In Afghanistan, many local communities have turned to traditional structures of dispute resolution: tribal councils known as jirga or shura. At the local level, such institutions operate in a timely manner and are accessible to the poor and illiterate. ${ }^{85}$ Although the Afghan Constitution does not incorporate these structures, with updating, they might be effectively included in a constitutional structure.

4. Know the Population. - Insurgency and counterinsurgency depend on the support, or at least the acquiescence, of the population. As a result, counterinsurgents must know who is in the population. The most effective ways to gain detailed knowledge of the population cannot be accomplished at the constitutional level, but a constitution can provide helpful background by requiring a census of the population. ${ }^{86}$ More controversially, a constitution could require issuance of identification cards. ${ }^{87}$ Both mechanisms could potentially assist in identifying members and groups within the population and within specific areas of the country.

\section{Tiered Constitutions and Mosaic Constitutionalism}

Counterinsurgency operates across many levels at once - global, national, provincial, and local. Counterinsurgents must establish national strategies, coordinate varying degrees of progress between provinces, and assist subnational and local entities. This focus on all levels of government, particularly the lower levels, engages the counterinsur-

\footnotetext{
84 S. AFr. CONST. I 996 ch. I $2, \S \S 2$ I I-2 I 2.

85 Int'L CRisis Group, Peacebuilding in Afghanistan i2-I4 (2003), available at http://www.crisisgroup.org/library/documents/asia/064__peacebuilding_in_afghanistan.pdf.

$86 \mathrm{Cf}$. GALula, supra note 5, at I I5-I8 (discussing the importance of a census).

87 Cf. id. at in6 (discussing identification cards); Sepp, supra note 72, at to (same).
} 
gent directly with the population it needs to win over. ${ }^{88}$ A tiered indigenous structure that parallels the tiered counterinsurgency structure could foster connectivity and cooperation between generals, colonels, and captains, and their counterparts.

Constitutional designers should consider tiered constitutions constitutions with subnational governance structures specified down to the precinct level. First, constitutionalizing local government has the potential to accelerate the counterinsurgent's project because the constitution would act as a focal point providing clear governance structures for local peoples to follow, while simultaneously pushing counterinsurgents toward transferring control to local people. Second, because core elements of counterinsurgency - providing social services and security - occur at the municipal level (or the equivalent), strengthening local public authorities is vital to undermining the insurgency and winning over the population. Third, including the populace more directly in political action, via participation in local governance, may aid in building legitimacy in public institutions. The result may be increased acceptance of both democracy and freedom. ${ }^{89}$ Fourth, establishing local government structures will also immediately create many local officeholders. With constitutional sanction, these officeholders will be formally empowered and accountable, thus facilitating legitimacy in their operations. And as these officials learn how to work the machinery of government, they will gain valuable skills in politics and governance, eventually forming a skilled class of future provincial and national leaders. Finally, constitutionalizing local government might actually be a way to protect constitutional rights. Because "local governments are often uniquely well positioned to give content to the substantive constitutional principles that should inform the consideration of [certain] public questions," they may facilitate and protect a burgeoning rights-based regime. ${ }^{90}$

At the local level, counterinsurgency is a mosaic process, requiring the counterinsurgents to go beyond military operations and a "killcapture" philosophy. They must enable security, build governance and political structures, facilitate capacity building and delivery of social services, and aid economic development and reconstruction. Constitutional design can facilitate each of these areas in the mosaic.

88 Cf. NAGL, supra note 20, at I59 (discussing the need for counterinsurgents to connect with the local population); Kilcullen, Twenty-Eight Articles, supra note 24, at 105-06 (same).

89 See Richard Briffault, Home Rule for the Twenty-First Century, 36 URB. LAW. 253, 258-60 (2004) (arguing that home rule advances the values of democracy, diversity, community, and innovation); Gerald E. Frug, The City as a Legal Concept, 93 HARV. L. REv. I057, I067-73 (1980) (arguing that city power can empower individuals to participate in social decisions, creating public freedom for individuals).

90 David J. Barron, The Promise of Cooley's City: Traces of Local Constitutionalism, I47 U. PA. L. REV. 487, 49I (I999). 
I. Security. - Ensuring security for the population is perhaps the most important factor for a successful counterinsurgency. Although counterinsurgents can provide some level of security, indigenous police will ultimately be responsible. Constitutionalizing the security services can at once empower and hold them - and the political leaders to whom they report - accountable for security conditions. Creating provincial- and district-level police chief positions that report to the respective political bodies and delineating their mode of selection would help quickly establish persons responsible for police training, patrols, and operations. Moreover, the constitution could mandate reporting and transparency, enable complaints and accountability, and establish controls and limits on the police. Indeed, the South African Constitution's provisions might act as a model, as they create a police force, establish political responsibility for the police force, and place limits and controls on the police. ${ }^{91}$

2. Governance and Political Structures. - Counterinsurgency requires building legitimate political structures from scratch. Because so many of the tasks government must accomplish are local, such as sewage maintenance, trash collection, and rebuilding infrastructure, local political structures are perhaps the best way to achieve these goals. Local participation is also likely the best way to build legitimacy - local government can enable "self-government and self-government."

As a result, constitutional designers should consider specifying political structures at the provincial, district/municipal, and precinct/village levels. In some cases, it might be possible to use traditional governance structures at the precinct or district level, but in many cases new institutions would be required. The constitution would need to mandate either how bodies at the precinct or district level would be selected or the procedures for choosing a selection mechanism. Identifying the body or bodies with primary responsibility for ensuring and providing social services and security would go a long way toward empowering and holding accountable specific actors at the local or regional level. Finally, constitutional designers should consider reporting mechanisms that link the levels of governance. ${ }^{93}$ Precincts could provide information to districts, and districts may need to provide progress reports to provinces.

\footnotetext{
91 S. AFR. CONST. I 996 ch. I I, \$§ 205-208.

92 i FRANCIS Lieber, ON CiVIl Liberty AND SELF-Government 277 (Adamant Media Corp. 2005) (I853).

93 See Int'l Crisis Group, IraQ: Can local Governance Save Central GovERNMENT? at i (2004), available at http://www.crisisgroup.org/library/documents/middle east_north_africa/iraq_iran_gulf/33_iraq_can_local_governance_save_central_gvnt.pdf (noting the importance of "improving communication between national ministries and local councils").
} 
Although the U.S. Constitution does not constitutionalize local government structures and functions, several other countries' constitutions do, and their provisions could be used as models. South Africa specifies the objects, composition, election, and even internal procedures of local governments and municipalities. ${ }^{94}$ The Dutch Constitution establishes election processes and structures for provinces and municipalities. ${ }^{95}$ The Indonesian Constitution identifies ways to create provinces, regencies, and municipalities. ${ }^{96}$ And the Afghan Constitution provides for provincial councils, giving them a role in development and charging them with encouraging political participation. ${ }^{97}$

3. Social Services. - In failed states, provision of basic social services is essential not only for sustaining a basic quality of life but also for preventing insurgency. Absence of basic services often correlates directly with insurgency, ${ }^{98}$ as populations see public power as less effective and legitimate and are willing to embrace insurgency. Constitutional designers might facilitate the delivery of social services in two simple ways: First, they could include a provision that allows a district or municipality to create public services authorities - such as water, sewage, and trash collection boards, or even fire companies - which would organize and supervise the provision of public services. For example, the Dutch Constitution specifies a process for the creation or dissolution of water control boards and other public bodies. ${ }^{99}$ Second, constitutional designers could provide for community empowerment projects $^{100}$ - a vehicle for villages or precincts to request domestic or international funding for specific infrastructure and development projects. Constitutionalizing these organizations would encourage local entities to act, involve the population in resolving challenges in their communities, and provide an officially sanctioned path for development organizations and NGOs to provide aid.

4. Economics and Budgetary Powers. - Reconstructing a society and building a functioning economy take money. Community-driven reconstruction and development would benefit from fiscal decentralization $^{101}$ to prevent waste, corruption, transaction costs, and delays in money transfers from the federal to the local governments, and to direct money toward the populations that can best identify and act upon

\footnotetext{
94 S. AFR. CONST. 1996 ch. $7, \S \S$ I 52 , I57, I60.

95 Gw. (Neth. Const.) ch. 7, arts. I $23-32$.

96 INDON. CONST. ch VI, art. I8.

97 AFG. Const. ch. 8, arts. I38-40.

98 Peter W. Chiarelli \& Patrick W. Michaelis, Winning the Peace: The Requirement for FullSpectrum Operations, MIL. REV., July-Aug. 2005, at 4, 9 fig.3.

99 Gw. (Neth. Const.) ch. 7, arts. I33-34.

100 See Rohland \& Cliffe, supra note I5, at I4.

$101 \mathrm{Cf}$. Briffault, supra note 89, at 26I-62 (arguing that fiscal capacity is one of the fundamental constraints on local home rule).
} 
the challenges they face. The constitution could require that part of the national budget be devolved to the provinces, districts, and precincts. ${ }^{102}$ The specific proportion could be established by law, but the constitution would mandate fiscal decentralization to encourage local development. The constitution could also grant local governments the power to levy taxes, in order to ensure a consistent stream of revenue for community-driven reconstruction and development. ${ }^{103}$ Fiscal decentralization places trust and responsibility in the hands of the local populations and their leaders. It encourages action through empowerment and fosters accountability.

5. The Challenge of Warlordism. - A difficult challenge arises when entrenching local power through constitutional provisions: local empowerment may amount to sanctioning warlordism. Warlords are primarily interested in their own benefit, not the development of the state. ${ }^{104}$ Working with warlords might condone the use of violence to gain power and undermine the moral authority of the counterinsurgent. ${ }^{105}$ However, warlords may also be the primary or only route to stability and security, and rejecting cooperation outright may rob the counterinsurgency of effective leaders who wish to "transition from "warlord to ward leader."'106 Moreover, the term "warlord" encompasses many meanings and practices, and some warlords may even provide social services, making their form of warlordism an effective form of governance. ${ }^{107}$ Whether to coerce or coopt warlords is therefore probably best determined on a case-by-case basis. Military and law enforcement power, prosecution and amnesty, and reduced, transparent, and dispersed funding may help diminish the influence of war-

102 INT'L CRISIs Group, supra note 93, at 29; see also Cliffe, Guggenheim \& Kostner, supra note $\mathrm{I} 3$, at $2 \mathrm{I}$.

103 See Cliffe, Guggenheim \& Kostner, supra note I3, at 2 I; see also INT'L CRISIS Group, supra note 93 , at 29 .

104 See Antonio Giustozzi, The Debate on Warlordism: The Importance of Military Legitimacy 5, I4 (London Sch. Econ. Crisis States Res. Ctr., Discussion Paper No. I3, 2005), available at http://www.crisisstates.com/download/dp/dpi 3.pdf.

105 See U.S. Inst. OF PEACE, UNFINISHEd Business in AFghanistan: WARLORdism, RECONSTRUCTION, AND ETHNIC HARMONY 4-5 (2003), available at http://www.usip.org/ pubs/specialreports/srio5.pdf; see also Jeremy I. Levitt, Illegal Peace?: An Inquiry into the Legality of Power-Sharing with Warlords and Rebels in Africa, 27 MICH. J. INT'L L. 495, 502, 506-08, 575,577 (2006).

106 See U.S. InST. OF PEACE, supra note I05, at 4-5.

107 See Daniel Biró, The (Un)bearable Lightness of ... Violence: Warlordism as an Alternative Form of Governance in the "Westphalian Periphery"?, in INST. FOR DEV. \& PEACE, STATE FAilure Revisited II: ACTORS OF Violence AND Alternative Forms of GovernANCE 7, 33-43 (Tobias Debiel \& Daniel Lambach eds., 2007), available at http://inef.unidue.de/page/documents/Report89.pdf; Conrad Schetter, Rainer Glassner \& Masood Karokhail, Beyond Warlordism: The Local Security Architecture in Afghanistan, INT'L POL. \& Soc'y, June 2007 , at $136, \mathrm{I}_{37}-48, \mathrm{I} 50$. 
lords, ${ }^{108}$ but because warlordism is the product of disorder, developing civil administration is the only sustainable solution. ${ }^{109}$

\section{CONCLUSION: SOLON'S GAMBIT}

The tasks of counterinsurgents and constitutional designers are interconnected. Counterinsurgency may influence the creation of constitutional order and the availability of particular constitutional provisions. Constitutional design can craft structures that assist counterinsurgents in their endeavor to establish a legitimate, stable government with political participation and functioning public power.

This complementarity has lessons for both constitutional designers and counterinsurgents. For constitutional designers, these interconnections require that they take military strategy more seriously. They must look beyond conventional ideas in constitutional engineering to craft provisions that are more closely tailored to the nation and the challenges it faces at the moment of creation. For counterinsurgents, these linkages underscore the significance of their project and the importance of particular choices. Most fundamentally, when constitutional creation and counterinsurgency occur simultaneously, constitutional designers and counterinsurgents must engage with one another, together structuring society to achieve their mutual goal of a secure, stable, and legitimate constitutional government.

The lessons of counterinsurgency for constitutional design follow from the lawgiver Solon's remark: the lawgiver must devise the best constitution a people can receive. Solon's gambit is the gambit of any constitutional designer interested in bridging the realities of the present with the ideals of political and constitutional philosophy. In the case of insurgency, the constitutional designer must gamble that compromise today to build sturdy foundations of order, stability, and shared values will lead eventually to the development of higher ideals and greater political and social justice. Even as they focus inexorably on the details of the moment, modern Solons must ultimately maintain a deep and abiding faith in the future - that with firm foundations, the constitution and the nation will adapt and develop over time.

108 James C. O'Brien, Lawyers, Guns, and Money: Warlords and Reconstruction After Iraq, I I U.C. DAVIS J. INT'L L. \& POL'Y 99, I00, I06-20 (2004).

109 Arthur Waldron, Research Note, Warlordism Versus Federalism: The Revival of a Debate?, I2 I CHINA Q. II6, I2 I-24 (I990). 